\title{
Seston particles along a eutrophication gradient in coastal waters of the Southern Baltic Sea: signifi- cance of detritus and transparent mucoid material
}

\author{
Rhena Schumann ${ }^{1, *}$, Daniel Rentsch ${ }^{2}$, Solvig Görs ${ }^{1}$, Ulrich Schiewer ${ }^{1}$ \\ ${ }^{1}$ University of Rostock, Department of Biosciences, Institute for Aquatic Ecology, Freiligrathstr. 7/8, 18051 Rostock, Germany \\ ${ }^{2}$ University of Rostock, Institute for Forensic Medicine, St. Georg-Str. 108, 18055 Rostock, Germany
}

\begin{abstract}
Exposed to over $30 \mathrm{yr}$ of continuous eutrophication, the Darß-Zingst bodden chain, a shallow tideless estuary accumulated large amounts of particulate organic matter (POM). We sampled along the eutrophication gradient throughout the vegetation period 1996, in order to assess POM properties. Besides parameters describing the chemical composition, such as $\mathrm{C} / \mathrm{N}$ ratio, protein content and protein:carbohydrate ratio, particles were microscopically analysed. From the volumes of non-transparent, nucleic acid-containing (fluorescently labelled by propidium iodide) and organic particles (stained with DTAF), the percentages of detrital and transparent mucoid material were derived. Ten to $63 \%$ of particulate organic carbon (POC) in the bodden system consisted of carbon from bacteria, phytoplankton and protozoans. Of the total organic particle volume, up to $46 \%$ were microorganisms. Although detritus volume averaged $14 \%$, maximum values of $68 \%$ could be determined. Most of the organic particle volume consisted to $64 \%$ of transparent mucoid matter, which is an important carbon compartment in material cycling (e.g. settling substrate). At higher POC concentrations the chemically unidentified material as well as the mucoid matter were quantitatively more important compared to the mesotrophic Baltic Sea station, where the portion of detritus (62\% on average) was much higher. The microscopically derived quantification of detrital and mucoid matter provides additional information on the suitability of seston as settling substrate, its age, origin and physical properties. Since the riverine water input into the bodden system is small and its POC concentration lower compared to the bodden itself, most of the estuarine POM was obviously produced locally. Detritus from submersed macrophytes did not occur before the end of the vegetation period in October and thus cannot contribute significantly to the POM analysed in this study. The high amounts of POM in the bodden system probably originate mainly from pelagic primary production. The sedimentation of POM, its processing in and frequent resuspension from the several mm-thick flocculent sediment layers, seems to be the main source for the high amount of mucoid particles.
\end{abstract}

KEY WORDS: Detritus · Transparent mucoid material · Microscopical analyses · Chemical composition of POM · Eutrophication gradient · Shallow estuary

\section{INTRODUCTION}

Estuaries and coastal waters have been investigated in order to assess the origin, age and fate of particulate organic matter (POM) in these important transition zones between land and ocean (isotopic composition of

*E-mail: rhena.schumann@biologie.uni-rostock.de carbon: Fichez et al. 1993; carbohydrate or fatty acid composition: Galois et al. 1996, Hernes et al. 1996; lignin content: Colombo et al. 1996; percentage of hydrolysable proteins: Fabiano \& Pusceddu 1998). The chemical composition of seston particles was used to estimate their value as food for zooplankton or other suspension feeders (Navarro et al. 1993, Jónasdóttir et al. 1995, Kreeger et al. 1997), or to predict the annual 
periodicity of phytoplankton (Aleya 1992, Hama \& Handa 1994, Michard et al. 1996, Sreepada et al. 1996).

Since most POM studies applied only single methods, a comprehensive assessment of POM quality is unavailable for most aquatic systems. The main aim of this study was a detailed description of the chemical value of seston particles: organic matter concentrations and elemental or substance distributions (Fig. 1a). These include the nitrogen availability ( $\mathrm{C}: \mathrm{N}$ ratio), the food value (essential amino acids, protein content), its microbial degradability and/or age ( $\mathrm{C}: \mathrm{N}$ ratio, protein content) etc. Moreover, we used different microscopical methods and an electronic particle sizer to investigate particle sizes and calculate their volumes (Fig. 1b). The different chemical parameters in combination with the microscopical investigations thus provide a data basis for a versatile valuation of POM.

All methods were applied to samples of a shallow, well-mixed, tideless and highly eutrophicated estuary, the Darß-Zingst bodden chain, and to samples from an outer coastal station. These boddens are semi-enclosed water basins with a salinity gradient caused by dominant high salinity Baltic Sea water from the east as opposed to a strong freshwater influence from the west. This leads to high eutrophication in the west as nutrients are brought by the freshwater, and increasing mesotrophic conditions as one moves to the east, due to the nutrient-poor water from the Baltic. These boddens are important for the retention of nutrients and the particles coming from the agricultural catchment area (Schlungbaum et al. 1994c). A 30 yr period of heavy nutrient input led to high eutrophication with a sub- stantial deposit of nitrogen, phosphorus and organic carbon in the sediments (Schlungbaum et al. 1994b). The aggregate formation in the sediment layer (Schumann \& Rentsch 1998), the shift in phytoplankton composition towards colony forming and mucus-rich cyanobacteria and chlorophyceae (Schumann 1993, Schiewer 1998) are all responsible for the quality and composition of POM in the Darß-Zingst boddens, which is dominated by mucoid and detrital constituents. The salinity gradient resulting from the gradually intensified Baltic Sea water inflow provides samples with gradually increasing POM concentrations and microbial biomasses from outer sea to inner stations. Therefore, parameters which describe POM composition can be related to its quantity values. It was of special interest to compare differences in organic matter composition with the eutrophication status of different stations.

\section{MATERIAL AND METHODS}

Investigation area. Plankton samples were taken between April and October 1996, at 5 stations along the Darß-Zingst bodden chain and at a station on the outer coast of the Baltic Sea, at least once a month (Fig. 2a). The Darß-Zingst bodden chain consists of several tideless lagoons connected by narrow streams allowing only very limited water exchange. The innermost bodden with the station Dierhagen is strongly exposed to freshwater and the outmost station is subject to a considerable water inflow from the Baltic Sea (Table 1, Fig. 2c; cf. Nausch \& Schlungbaum 1991).

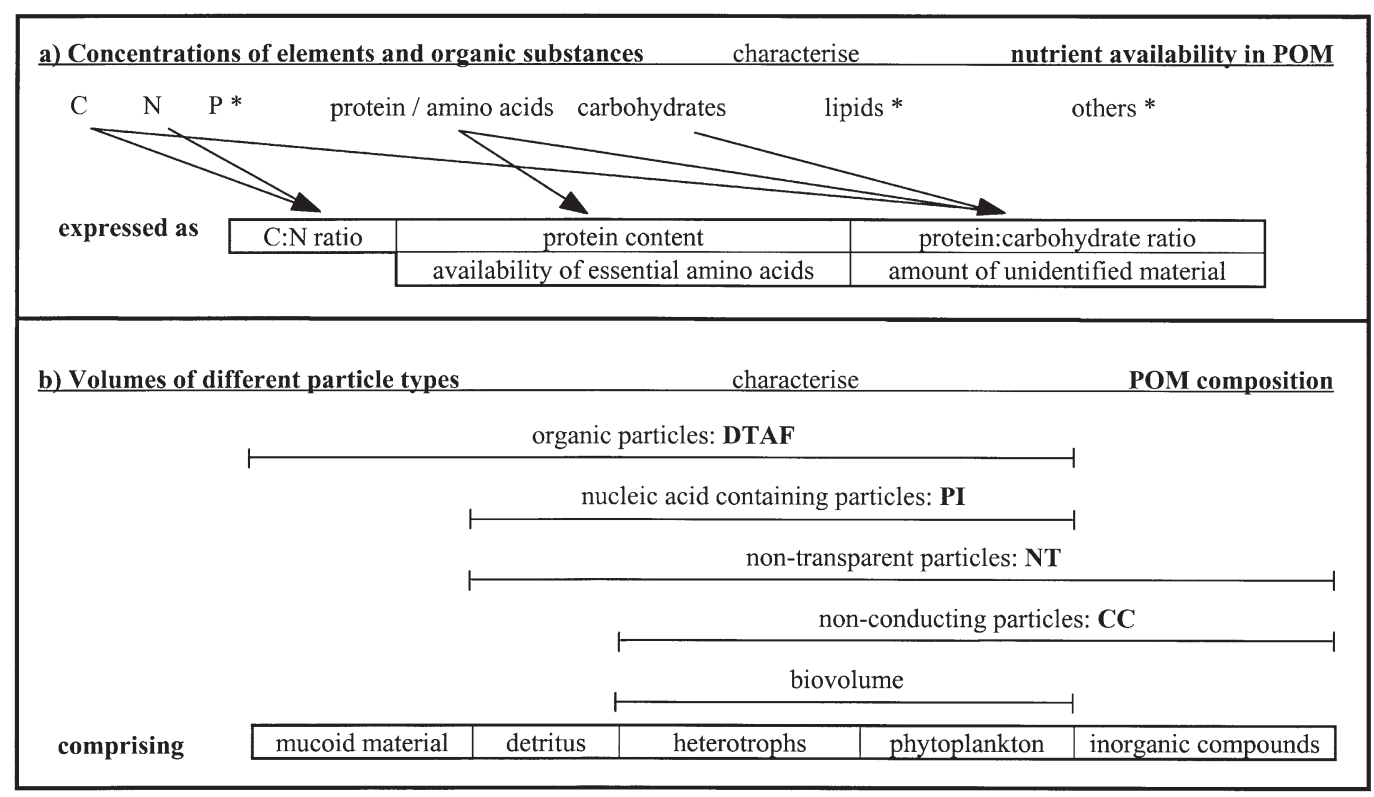

Fig. 1. Survey of the applied methods for chemical, physical and microscopical POM characterisation and the possible conclusions concerning the quality of seston particles. *Parameters not measured in this study 


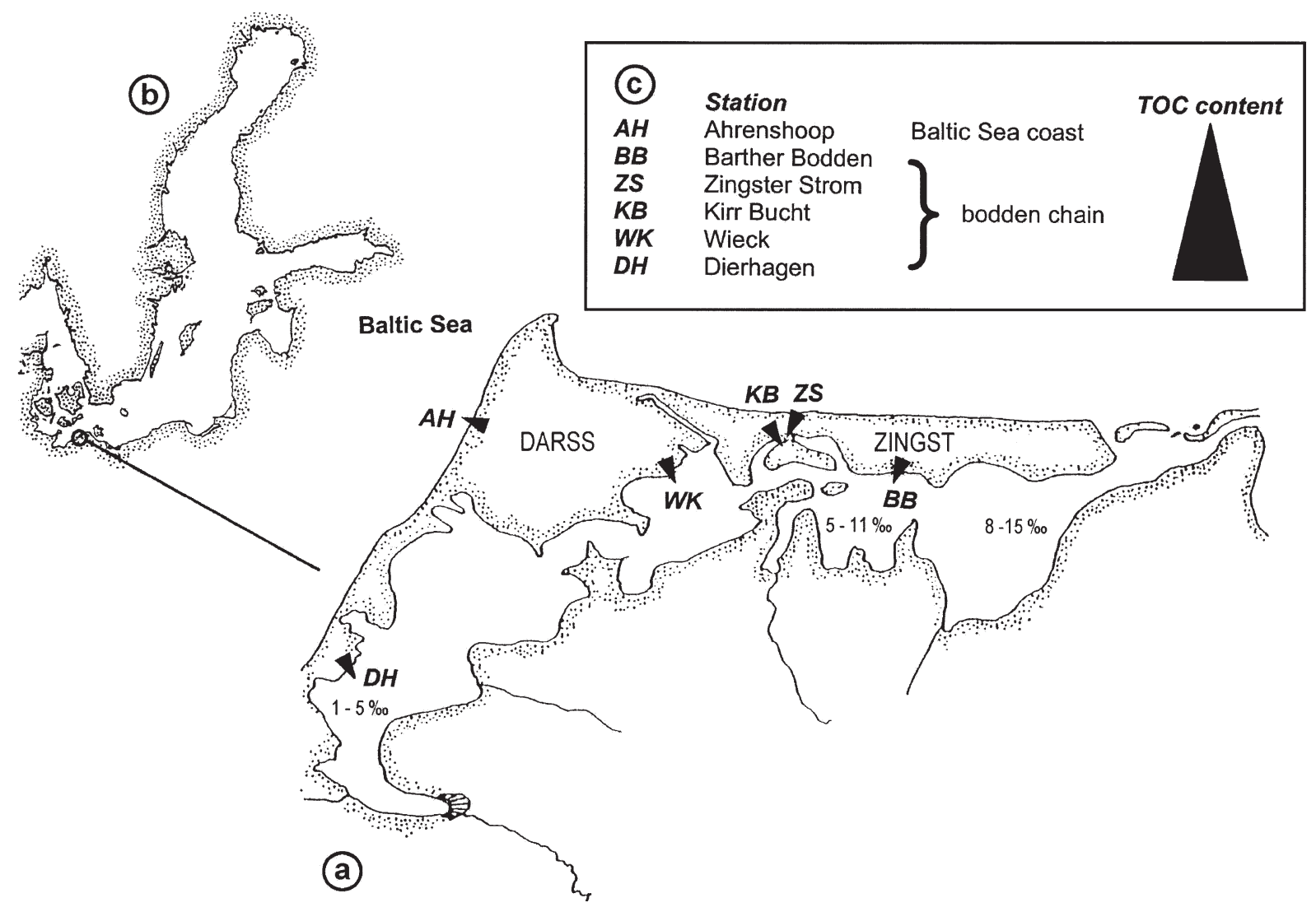

Fig. 2. Sampling area of the Darß-Zingst bodden chain (a) in the Southern Baltic Sea (b) with all sampling stations. (c) Station names including their abbreviations in order of increasing TOC content

Table 1. Differences between the Baltic Sea coast (Ahrenshoop) and in the 5 bodden stations observed from April to October 1996 in average salinities (PSU), water temperatures $\left({ }^{\circ} \mathrm{C}\right)$, Secchi-depth $(\mathrm{cm}), \mathrm{pH}$, oxygen saturation $(\%)$, inorganic $\mathrm{N}\left(\mu \mathrm{mol} \mathrm{N}^{-1}\right)$, DOC, POC $\left(\mu \mathrm{mol} \mathrm{l} \mathrm{l}^{-1}\right)$, phytoplankton biovolumes $\left(\mathrm{mm}^{3} \mathrm{l}^{-1}\right)$, bacterial cell numbers $\left(10^{6} \mathrm{ml}^{-1}\right)$ and POM quality as carbohydrate, protein and phytoplankton contributions to POC ( $\mu \mathrm{mol} \mathrm{C} / \mu \mathrm{mol} \mathrm{C} ; \%), \mathrm{C}: \mathrm{N}$ ratios and protein: carbohydrate ratios (PAA:PCHO) $(\mu \mathrm{mol} \mathrm{C} / \mu \mathrm{mol} \mathrm{C})$ all determined by the pairwise multiple comparison procedure (Student-Newman-Keuls, $\mathrm{p}<0.05:<$ or $>$ denote significant difference between neighbour station or stations marked in bold or bold italics) after Kruskal-Wallis 1-way ANOVA on ranks (Test Statistic $H$, values represent median) or in the case of normally distributed data after 1-way ANOVA (Test Statistic $F$, figures are arithmetic means). -: no data

\begin{tabular}{|c|c|c|c|c|c|c|c|c|c|c|}
\hline & Statisitics & $\mathrm{AH}$ & & $\mathrm{BB}$ & & ZS & $\mathrm{KB}$ & WK & & $\mathrm{DH}$ \\
\hline \multicolumn{11}{|l|}{ Abiotic factors } \\
\hline Salinity & $F=63$ & 10.4 & $>$ & 6.4 & $>$ & 5.5 & 5.5 & 5.0 & $>$ & 3.3 \\
\hline Water temperature & $F=2$ & 11 & & 15 & & 16 & 17 & 15 & & 14 \\
\hline Secchi depth & $F=5$ & - & & 46 & $>$ & 38 & 36 & 35 & & 29 \\
\hline $\mathrm{PH}$ & $F=10$ & 8.1 & $<$ & 8.6 & & 8.8 & 8.7 & 8.7 & & 8.8 \\
\hline Oxygen saturation & $H=1$ & 110 & & 104 & & 101 & 96 & 104 & & 100 \\
\hline Inorganic N & $H=4$ & 25 & & 27 & & 32 & 30 & 34 & & 37 \\
\hline \multicolumn{11}{|c|}{ Quantity of organic matter } \\
\hline DOC & $H=24$ & 318 & $<$ & 824 & & 918 & 957 & 920 & & 1018 \\
\hline POC & $F=15$ & 31 & $<$ & 421 & & 634 & 940 & 920 & $<$ & 1162 \\
\hline Phytoplankton & $H=32$ & 0.1 & $<$ & 7.6 & & 12.6 & 14.6 & 14.0 & $<$ & 21.5 \\
\hline Bacteria & $H=29$ & 2.2 & $<$ & 13.1 & $<$ & 22.4 & 22.9 & 18.2 & & 23.7 \\
\hline \multicolumn{11}{|l|}{ Contribution to POC } \\
\hline Carbohydrates & $F=4$ & 51 & $>$ & 20 & & 24 & 18 & 23 & & 22 \\
\hline Protein & $H=5$ & 57 & & 65 & & 22 & 21 & 22 & & 25 \\
\hline Phytoplankton & $F=3$ & 8 & $<$ & 23 & & 22 & 14 & 17 & & 23 \\
\hline \multicolumn{11}{|l|}{$\mathbf{N}$ availability } \\
\hline $\mathrm{C}: \mathrm{N}$ & $F=5$ & 6.9 & $<$ & 8.8 & & 10.1 & 10.2 & 10.4 & & 10.6 \\
\hline
\end{tabular}


Connected to this salinity gradient is a eutrophication ascent from eutrophic conditions in the outer parts to hypertrophic waters in the inner bodden (Wasmund 1989, Wasmund \& Kell 1991). In all Figs and Tables the stations were arranged according to their average total organic carbon (TOC) concentrations beginning with the outer coastal station and ending with the innermost bodden station (Fig. 2c). Due to frequent strong west winds and a mean depth of $2 \mathrm{~m}$, the water bodies have always totally mixed water columns. Resuspension of particulate material from the fluffy sediment layer and its sedimentation under calm conditions influence POM concentration and composition considerably, albeit unpredictably.

Inorganic nitrogen compounds peak annually from January to March with maximum concentrations of e.g. 100 to $600 \mu \mathrm{mol} \mathrm{l}^{-1}$ for nitrate. During late spring and summer, concentrations of nitrate, ammonium and $o$-phosphate rarely exceed $2 \mu \mathrm{mol} \mathrm{l}^{-1}$ (Schlungbaum et al. 1994b). The hydrological circumstances (low water column, heavily loaded sediments and frequent sediment resuspension) are favourable for the release of plant nutrients into the pelagial (Schlungbaum et al. 1994a, Rieling et al. 1999). This, however, can be interrupted by active microphytobenthos (Rieling et al. 2000). Compared to preceding years, 1996 was fairly cold. Due to the persistent ice cover for several months, scarce rainfall and ground frost, which diminished wash out from land, nitrogen concentrations in winter reached only $50 \%$. Soluble reactive phosphorus declined continuously to values between 0.5 and $2 \mathrm{umol}^{-1}$ as monthly means in the inner coastal waters since 1990 (Gewässergütebericht Mecklenburg-Vorpommern 1996/97).

Abiotic parameters. Temperature and oxygen concentration were measured with the OXI 196, salinity with a LF 197 electrode (wtw, Weilheim), expressed as practical salinity units (PSU) and $\mathrm{pH}$ with a pH-Meter 765 Calimatic (Knick, Berlin). Ammonium, nitrate and nitrite were estimated spectrophotometrically in Whatman GF/F filtrates following the methods described in Grasshoff et al. (1983).

Chemical analysis of particulate organic matter (POM). For the quantification of TOC, unfiltered subsamples were analysed with a total organic carbon analyser (TOC 5000 A, Shimadzu) equipped with a suspended particle kit after catalytic high temperature oxidation (Sugimura \& Suzuki 1988). The filtrate obtained from precombusted $\left(450^{\circ} \mathrm{C}\right.$ for $\left.4 \mathrm{~h}\right)$ Whatman GF/F glass-fibre filters was measured for dissolved organic carbon (DOC). Both results were corrected for inorganic carbon (IC). Particulate organic carbon (POC) was calculated as the difference of TOC and DOC. Organic carbon was analysed in 3 replicates with a standard error $<2 \%$.
Total carbohydrates (TCHO) loads were estimated with the MBTH-method according to Burney \& Sieburth (1977) after chemical hydrolysis. The standard compound was soluble starch and the carbon content was calculated from its molar ratio. Particulate carbohydrates (PCHO) were calculated by subtracting dissolved carbohydrates (DCHO) as measured by the same method for GF/F filtrates. The standard error of 3 replicates was less than $10 \%$ at a concentration of

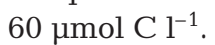

Amino acids were derivatised with OPA (o-phthaldialdehyde, modified after Hubberten 1994). The fluorescent products were separated and quantified by HPLC (Lindroth \& Mopper 1979). Reference compounds were amino acids from the amino acid standard H (Pierce, No. 20088). The concentration of each amino acid was quantified and converted to carbon. Total hydrolysable amino acids (THAA) were corrected for dissolved (hydrolysable and free) amino acids (DAA) found in the GF/F filtrate. The result was interpreted as particulate protein or particulate (hydrolysable) amino acids (PAA). The standard error of triplicate determinations of 1 hydrolysate was $<20 \%$. Hydrolysates were measured in duplicates and differed by $<7 \%$. The amount of chemically unidentified material was calculated by subtracting PAA and $\mathrm{PCHO}$ from POC.

The dissolved organic nitrogen (DON) was calculated as the difference of the total dissolved nitrogen (DN) and the dissolved inorganic nitrogen (DIN as the sum of ammonium, nitrite and nitrate). DN was determined in GF/F filtrates according to the method for total nitrogen (Grasshoff et al. 1983). The results are based on duplicates.

For estimating the C:N ratio of POM, 5 to $50 \mathrm{ml}$ were filtered onto Whatman GF/F and dried at $60^{\circ} \mathrm{C}$. IC was expelled in an $\mathrm{HCl}$-atmosphere for 20 min. The filters were packed air-tied in tin foil and measured in an elementar analyser (elementar vario EL) for carbon and nitrogen following the protocol of Verardo et al. (1990). Triplicates had a standard error of $<5 \%$.

Microbial biomass. Phytoplankton cells were counted in Lugol fixed samples under an inverted microscope (Lund et al. 1958, Utermöhl 1958). Diameters were measured to calculate cell volumes (Edler et al. 1979) and carbon was estimated with $11.25 \%$ carbon per fresh weight (Heerkloß \& Vietinghoff 1981) at a specific density of $1.04 \mathrm{~g} \mathrm{~cm}^{-3}$. Bacteria were counted after staining with DAPI (Porter \& Feig 1980). Their biomasses were determined with an individual cell volume of $0.037 \mu^{3}$ (Jost unpubl.) for the Baltic Sea samples and $0.15 \mu \mathrm{m}^{3}$ for the bodden samples as used in Klinkenberg \& Schumann (1995). A size-specific carbon conversion factor was applied depending on cell size (Simon \& Azam 1989). Protozoa were quanti- 
fied alive (Dale \& Burkill 1982) in a rafter chamber containing 0.5 to $1 \mathrm{ml}$ sample for ciliates and larger flagellates, and in a blood counting chamber for smaller flagellates $(<10 \mu \mathrm{m})$. Ciliate and flagellate abundances of individuals larger than $20 \mu \mathrm{m}$ were rechecked in the Lugol fixed samples during phytoplankton analysis. Carbon contents of $8.55 \%$ of fresh weight for ciliates and $11.25 \%$ for flagellates (Heerkloß \& Vietinghoff 1981) were applied to estimate carbon biomass. The total biovolumes of phytoplankton, bacteria and protozoa are referred to as (microbial) biovolume (Fig. 1b).

Particle volume estimation. Another way of describing $\mathrm{POM}$ is the determination of particle size and volume. With a Coulter Counter ${ }^{\circledR}$ Multisizer II using a $70 \mu \mathrm{m}$ orifice capillary particles up to an equivalent sphere diameter (ESD) of $42 \mu \mathrm{m}$ were measured. Since only non-conducting particles are sized correctly, organisms with an intact membrane and inorganic particles were properly counted for the determination of total particle volume (Fig. 1b). Conducting material, such as mucoid substances and detritus, was underestimated by up to $70 \%$ (Boyd \& Johnson 1995).

To compensate for these inaccuracies, particles were additionally investigated with an image analysis system (CUE 2, Galai, Israel) and an epifluorescence microscope (BH2-RFCA, Olympus). Different physical and chemical properties of seston were used to quantify particles and their sizes. The total volume was calculated from longest and smallest diameters under the assumption of a spheroid. Organic matter, including organisms as well as mucoid (and transparent) material or protein colloids, was stained with the fluorescent dye DTAF, which binds covalently to carbohydrates and proteins. The green fluorescing particles were monitored at a magnification of 200 with a low light video camera HL 5 (Proxitronic, Bensheim, Germany). These results were compared to objects binding the nucleic acid-specific fluorochrome propidium iodide (PI); thus, staining organisms and detritus derived from them. The same nucleic acid-specific stain was used by Williams et al. (1995) and Duarte et al. (1999) to visualise detritus. Organic particles (DTAF) without nucleic acids were considered as transparent (exo)polymeric or mucoid material and perhaps as colloids of protein (cf. Fig. 1b and Schumann \& Rentsch 1998). The difference of the nucleic acid containing particles (PI) and biovolume is interpreted here as detritus. Thus, according to our definition detritus excludes extracellular or mucoid material since this should not contain nucleic acids.

After settling in sedimentation chambers, non-transparent particles (NT) consisting of plankton organisms, detritus and inorganic particles or components were analysed by light microscopy and the same image analysis system at a magnification of 100 .
Statistical analysis. Differences between average concentrations found at various stations were detected by 1-way ANOVA if the data passed normality test. In that case, average concentrations are the arithmetic means. However, the majority of data was not distributed normally and therefore variances were analysed by Kruskal-Wallis 1-way analysis on ranks. Hence, the medians serve as average values. High values of the test statistics $F$ from 1-way ANOVA and $H$ of KruskalWallis ANOVA on ranks indicate differences in average values across stations. A critical $p$-value of $<0.05$ was always applied. The all pairwise multiple comparison Student-Newman-Keuls method was used to isolate the significantly differing values.

To prove associations between concentrations and/ or POM composition parameters, a Spearman rank order correlation analysis was performed on the whole data set. Because of the particular situation at the outer coastal station $(\mathrm{AH})$, which is not influenced by bodden or freshwater inflow, the data of this station were not included in the analysis, but shown in the scatter plots.

\section{RESULTS}

\section{Abiotic factors and plankton}

Based on DIN, Secchi depth, pH or phytoplankton, the Baltic Sea station (AH) and the outer bodden station (BB) were mesotrophic and the 4 inner stations eutrophic. The whole Darß-Zingst bodden chain was declared heavily eutrophic in 1994 and eutrophic in 1995 (Schlungbaum 1997, Gewässergütebericht Mecklenburg-Vorpommern 1996/97). Because salinity numerically distinguished the different stations, it was used instead of eutrophication ranks as the independent parameter in the correlation and variance analysis. High salinity (10.4 PSU) stands for mesotrophic Baltic Sea water influence and low salinity (3.3 PSU) for heavy eutrophic brackish water (Table 1). The innermost station $(\mathrm{DH})$ was the station with the strongest freshwater influence. Although the intermediate 4 stations differed in salinity, this was not statistically significant.

Phytoplankton samples from $\mathrm{AH}$ were dominated by dinoflagellates $(27 \%$ of phytoplankton biomass on average), cyanobacteria (35\%) or diatoms $(34 \%)$. Biomass from the bodden stations was at least 14-times higher than at $\mathrm{AH}$. In the boddens, phytoplankton was dominated by cyanobacteria ( $45 \%$ ) and chlorophyceae (41\%) (Fig. 3a). All bodden stations had a similar species composition. Only the most eutrophicated station (DH) exhibited a significantly higher phytoplankton biomass (Table 1). 
Bacterial cell numbers were 10-times lower at $\mathrm{AH}$ compared to the 4 innermost bodden stations. Within the bodden system, only BB had significantly lower bacterial cell numbers (Table 1). Protozoa contributed

a) phytoplankton biomass [ $\mu \mathrm{mol} \mathrm{C}_{1} \mathrm{l}^{-1}$ ]
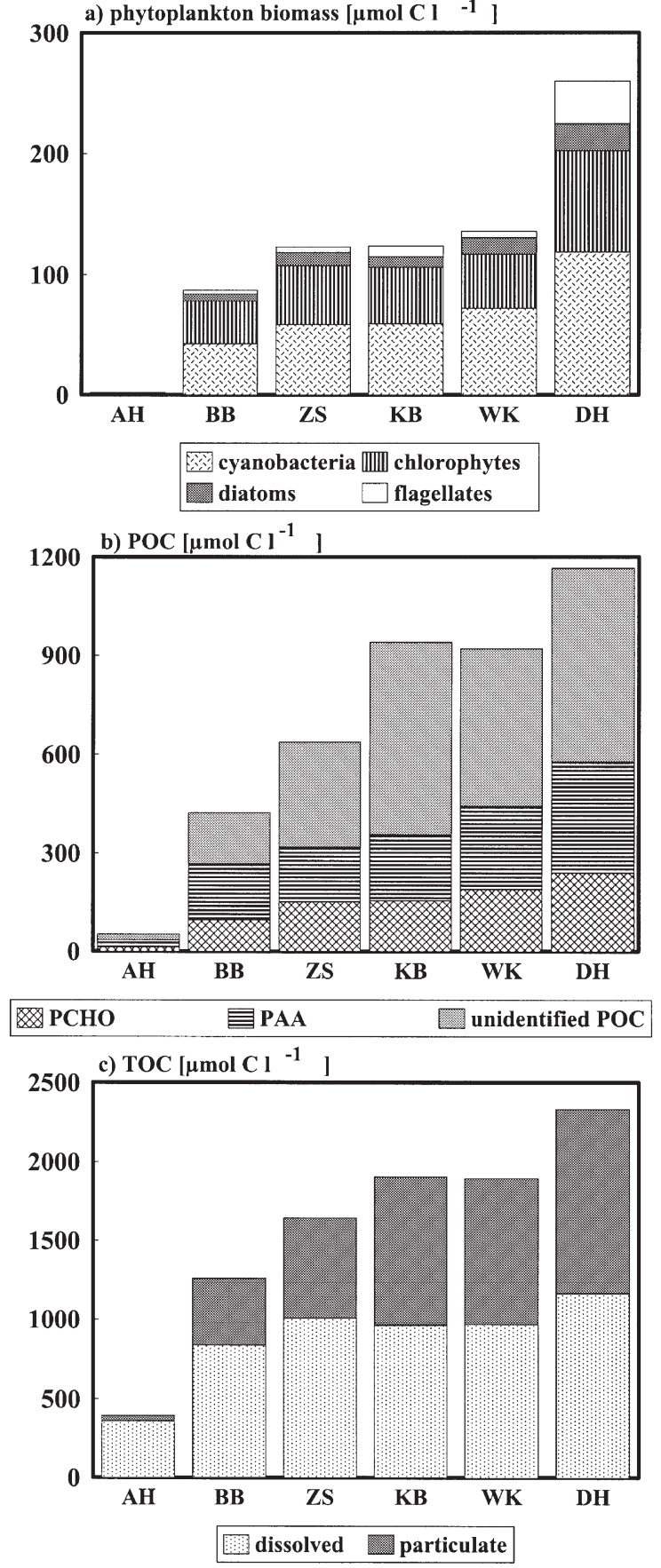

Fig. 3. (a) Phytoplankton biomasses, (b) carbohydrates (PCHO), amino acids (PAA) and chemically unidentified particulate organic carbon (unidentified POC), (c) dissolved and

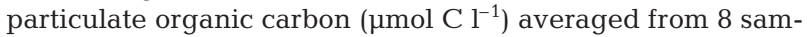
ples (April to October 1996) only $4 \%$ to microbial biomass in the bodden system, but $14 \%$ at the Baltic Sea coast. Neither mean biomasses nor maximal values of any organism group followed the eutrophication gradient in the bodden system (Table 2).

\section{POM quantity and its chemical composition}

POC, particulate carbohydrates and phytoplankton increased slightly from spring until late summer at all stations. Whereas at AH, DOC exceeded POC concentrations by up to 32-times, at the bodden stations POC was on average equal to DOC. Average TOC followed the eutrophication gradient from $\mathrm{BB}$ to $\mathrm{DH}$ well (Fig. 3c). Significant differences of POC concentrations did occur, but not between neighbouring stations (Table 1).

Since carbohydrate and protein concentrations increased only slightly with the POC content (Fig. 3b), the unidentified portion of POC was greatest at high POC concentrations. At $\mathrm{AH}$ the portions of carbohydrates (37\% of POC) and of protein (58\% of POC) were higher than at the bodden stations where carbohydrates and protein contributed to POC by 21 and $34 \%$, respectively. Only $\mathrm{BB}$ had a higher protein portion (53\% of POC).

Biomass division into systematic groups was very similar at all bodden stations and in sharp contrast to AH. In the Darß-Zingst bodden chain, phytoplankton dominated the microbial biomass with $72 \%$. Including heterotrophs, no more than $25 \%$ of POC could be classified as carbon converted microbial biomass (Table 2). At $\mathrm{AH}$, bacteria were more important and accounted for $44 \%$ of biomass. Phytoplankton was less important (29\% of microbial biomass). However, the contribution of total microbial biomass to POC averaged at $28 \%$ at the marine site, which was comparable to the $25 \%$ average at the bodden stations.

\section{Composition of particles determined on a volume basis}

Very small particles $(<2.7 \mu \mathrm{m}$ ESD) were dominant at all stations. Particles larger than $27 \mu \mathrm{m}$ ESD counted $<1 \%$ (Table 3 ). About $75 \%$ of the particle volume was contributed by the 2.7 to $27 \mu \mathrm{m}$ size class, which covered approximately the nanoplankton fraction. Whereas only 2 to $23 \%$ of the non-transparent particle volume were found in the largest size class, the biggest, but rare, organic particles contributed 5 to $37 \%$ of the total organic particle volume. Most of the voluminous particles seemed to consist of transparent biopolymers. 
Table 2. Average carbon converted biomasses $\left(\mathrm{mg} \mathrm{C}^{-1}\right.$ ), their contribution (\%) to total microbial biomass and POC and biovolume percentage of organic particles volumes calculated from DTAF-stainable objects (all averages are medians; range in parentheses) at the Baltic Sea coast (AH) and in the 5 bodden stations observed from April to October 1996

\begin{tabular}{|c|c|c|c|c|c|c|}
\hline & $\mathrm{AH}$ & BB & $\mathrm{ZS}$ & KB & WK & $\mathrm{DH}$ \\
\hline \multicolumn{7}{|l|}{ Carbon biomass } \\
\hline Phytoplankton & $\begin{array}{c}0.017 \\
(0.002-0.053)\end{array}$ & $\begin{array}{c}0.9 \\
(0.8-2.1)\end{array}$ & $\begin{array}{c}1.5 \\
(0.7-2.0)\end{array}$ & $\begin{array}{c}1.7 \\
(0.7-2.0)\end{array}$ & $\begin{array}{c}1.7 \\
(0.9-2.6)\end{array}$ & $\begin{array}{c}2.6 \\
(1.5-5.7)\end{array}$ \\
\hline Bacteria & $\begin{array}{c}0.024 \\
(0.013-0.062)\end{array}$ & $\begin{array}{c}0.32 \\
(0.20-0.50)\end{array}$ & $\begin{array}{c}0.56 \\
(0.41-0.62)\end{array}$ & $\begin{array}{c}0.57 \\
(0.41-0.62)\end{array}$ & $\begin{array}{c}0.45 \\
(0.23-0.80)\end{array}$ & $\begin{array}{c}0.59 \\
(0.28-1.23)\end{array}$ \\
\hline Protozoa & $\begin{array}{c}0.005 \\
(0-0.080)\end{array}$ & $\begin{array}{c}0.047 \\
(0-0.153)\end{array}$ & $\begin{array}{c}0.100 \\
(0.005-0.197)\end{array}$ & $\begin{array}{c}0.096 \\
(0.031-0.212)\end{array}$ & $\begin{array}{c}0.083 \\
(0.011-0.247)\end{array}$ & $\begin{array}{c}0.115 \\
(0.004-0.542)\end{array}$ \\
\hline \multicolumn{7}{|c|}{ Contribution to total microbial biomass } \\
\hline Phytoplankton & $29(6-78)$ & $72(61-83)$ & $68(47-80)$ & $71(48-80)$ & $75(64-79)$ & $78(72-86)$ \\
\hline Bacteria & $44(21-76)$ & $24(15-30)$ & $26(17-40)$ & $24(19-44)$ & $23(16-30)$ & $19(5-26)$ \\
\hline Protozoa & $14(0-71)$ & $4(0-8)$ & $4(8-12)$ & $5(0-8)$ & $3(8-14)$ & $3(1-13)$ \\
\hline \multicolumn{7}{|l|}{ Contribution to POC } \\
\hline Phytoplankton & $3(1-26)$ & $25(13-33)$ & $19(11-36)$ & $13(6-23)$ & $14(8-40)$ & $18(11-49)$ \\
\hline Total microbial biomass & $28(3-48)$ & $34(22-49)$ & $26(21-54)$ & $19(10-32)$ & $18(12-53)$ & $24(15-63)$ \\
\hline \multicolumn{7}{|c|}{ Contribution to organic particle volume } \\
\hline Phytoplankton & $2(0-7)$ & $18(4-35)$ & $16(6-26)$ & $23(5-39)$ & $18(2-29)$ & $21(11-39)$ \\
\hline Total biovolume & $7(1-31)$ & $23(5-46)$ & $22(11-36)$ & $29(7-46)$ & $24(2-35)$ & $26(14-46)$ \\
\hline
\end{tabular}

Table 3. Contribution of different particle size classes to total particle number and volume (\%) measured as non-transparent (NT), organic (DTAF) and nucleic acid-containing (PI) particles averaged of 8 observations between April and October $1996.10 \mu \mathrm{m}^{3}=$ $2.7 \mu \mathrm{m} \mathrm{ESD;} 10000 \mu \mathrm{m}^{3}=27 \mu \mathrm{m} \mathrm{ESD}$

\begin{tabular}{|c|c|c|c|c|c|c|}
\hline \multirow{2}{*}{$\begin{array}{l}\text { Size classes: } \\
\text { NT }\end{array}$} & \multirow[t]{2}{*}{$<10 \mu \mathrm{m}^{3}$} & \multicolumn{2}{|c|}{$\begin{array}{l}\text { Number } \\
10 \text { to } 10000 \mathrm{~m}^{3}>10000 \mu^{3}\end{array}$} & \multirow[t]{2}{*}{$<10 \mu \mathrm{m}^{3}$} & \multicolumn{2}{|c|}{$\begin{array}{l}\text { Volume } \\
10 \text { to } 10000 \mathrm{~m}^{3}>10000 \mu^{3}\end{array}$} \\
\hline & & & & & & \\
\hline $\mathrm{AH}$ & 64.4 & 35.3 & 0.3 & 3.0 & 74.0 & 23.0 \\
\hline BB & 80.9 & 19.1 & 0.0 & 15.1 & 78.1 & 6.8 \\
\hline ZS & 81.8 & 18.2 & 0.0 & 17.9 & 73.4 & 8.7 \\
\hline KB & 80.2 & 19.8 & 0.0 & 14.9 & 79.5 & 5.6 \\
\hline WK & 82.7 & 17.3 & 0.0 & 18.0 & 77.1 & 4.9 \\
\hline DH & 81.2 & 18.8 & 0.0 & 16.7 & 81.5 & 1.8 \\
\hline \multicolumn{7}{|l|}{ DTAF } \\
\hline $\mathrm{AH}$ & 75.2 & 24.4 & 0.4 & 1.2 & 61.8 & 37.0 \\
\hline BB & 79.3 & 20.7 & 0.0 & 6.1 & 80.0 & 13.9 \\
\hline $\mathrm{ZS}$ & 77.1 & 22.9 & 0.0 & 7.3 & 93.2 & 9.5 \\
\hline KB & 73.9 & 26.0 & 0.1 & 6.4 & 64.0 & 29.6 \\
\hline WK & 79.6 & 20.4 & 0.0 & 7.1 & 76.7 & 16.2 \\
\hline $\mathrm{DH}$ & 80.0 & 20.0 & 0.0 & 6.1 & 75.6 & 18.3 \\
\hline \multicolumn{7}{|l|}{ PI } \\
\hline $\mathrm{AH}$ & 79.2 & 20.7 & 0.1 & 1.3 & 83.1 & 15.6 \\
\hline BB & 88.4 & 11.6 & 0.0 & 7.6 & 75.9 & 16.5 \\
\hline $\mathrm{ZS}$ & 90.0 & 10.0 & 0.0 & 8.8 & 70.9 & 20.3 \\
\hline KB & 83.7 & 16.2 & 0.1 & 7.1 & 67.1 & 25.8 \\
\hline WK & 91.3 & 8.7 & 0.0 & 9.6 & 78.4 & 12.0 \\
\hline DH & 90.6 & 9.4 & 0.0 & 9.8 & 85.1 & 5.1 \\
\hline
\end{tabular}

In 13 out of 48 samples, the volume of nucleic acid containing particles equalled the microbial biovolume, so that the volume of detritus was negligible (Table 4). Compared to total organic particle volume (DTAF) the biovolume of phytoplankton accounted for up to $7 \%$ at $\mathrm{AH}$, but for maximally $46 \%$ at the bodden stations (Table 2). Heterotrophic biovolume contributed to org- anic particle volume $7 \%$ at the Baltic Sea coast and 5\% in the boddens. Maximal values occurred in $\mathrm{AH}$ with $99 \%$ of total organic value. On average, the samples from $\mathrm{AH}$ contained $58 \%$ more detritus than the bodden samples which had 14\%. Except for 3 samples from $\mathrm{AH}$, in all other samples significant portions of mucoid material were detected. On average, $64 \%$ of 
Table 4. Average and range of different particle volumes $\left(\mu \mathrm{l}^{-1}\right)$. (CC: measured with the Coulter ${ }^{\circledR}$ Counter, biovolume: sum of bacterial, protozoan and phytoplankton volumes, NT: non-transparent, PI: nucleic acid-containing and DTAF: organic material). Average, minimal and maximal contribution (\%) of detritus and mucoid material to total particle volume (all averages are medians; range in parentheses) at the Baltic Sea coast (AH) and in the 5 bodden stations observed from April to October 1996

\begin{tabular}{|lcccccc|}
\hline & AH & BB & ZS & KB & WK \\
\hline Particle volume & & & & & DH \\
CC & $4(3-8)$ & $29(17-49)$ & $31(22-56)$ & $39(19-47)$ & $50(25-90)$ & $75(57-84)$ \\
NT & $5(1-29)$ & $14(6-127)$ & $22(15-67)$ & $25(7-57)$ & $30(16-66)$ & $37(20-111)$ \\
Biovolume & $0.5(0.2-1.3)$ & $10(9-20)$ & $17(12-21)$ & $18(10-22)$ & $17(11-27)$ & $28(16-56)$ \\
PI & $4(1-24)$ & $18(7-98)$ & $15(12-50)$ & $23(12-44)$ & $34(10-63)$ & $51(22-110)$ \\
DTAF & $11(2-15)$ & $48(26-175)$ & $86(38-152)$ & $62(35-130)$ & $104(42-611)$ & $111(85-194)$ \\
Detritus portion & $62(0-80)$ & $20(0-68)$ & $6(0-21)$ & $14(0-56)$ & $18(0-57)$ & $15(0-43)$ \\
Mucoid material & $31(0-80)$ & $55(24-73)$ & $73(60-87)$ & $57(26-90)$ & $62(8-90)$ & 55 \\
\hline
\end{tabular}

DTAF of the bodden samples consisted of transparent particulate organic material. That was twice as much as the $33 \%$ in $\mathrm{AH}$ (Fig. 4).

Although volumes determined by the electronic particle sizer greatly underestimate detrital material, the average total volumes often exceeded the volumes of nucleic acid-containing particles - living and dead cells (Table 4). The contribution of inorganic material to total volume of non-conducting particles seems to be important.

\section{POM composition related to abiotic parameters and POM concentration}

Temperature itself was not an important impact factor for organic matter properties during spring and

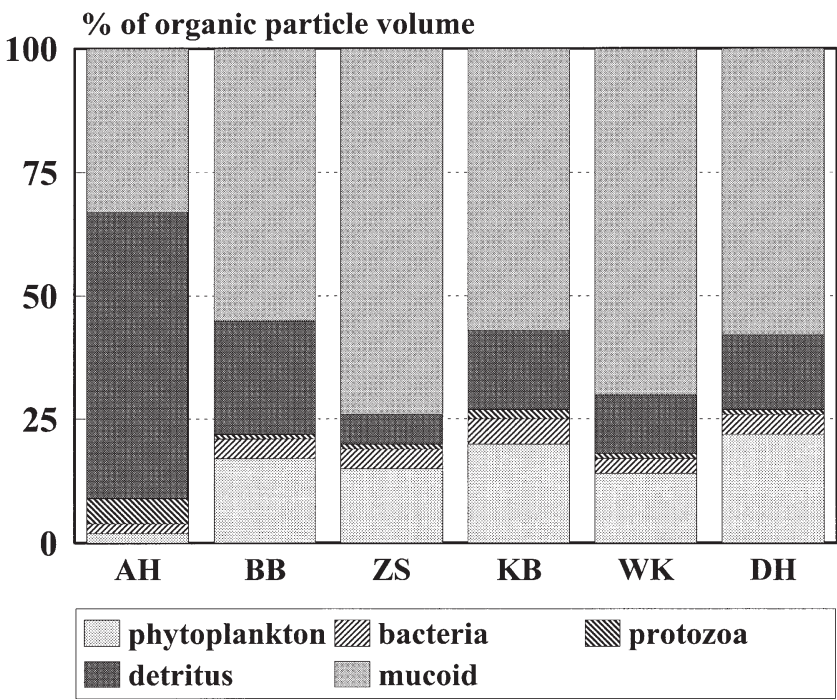

Fig. 4. Average composition of total organic particle volume (DTAF) of bacteria, protozoa, phytoplankton, detritus (PI-biovolumes) and mucoid material (DTAF-PI) at the Baltic Sea coast near Ahrenshoop (AH) and the 5 bodden stations. April to October 1996 (arithmetic means, $\mathrm{n}=8$ ) summer at temperatures above $10^{\circ} \mathrm{C}$. Higher $\mathrm{pH}$-values due to intensive primary production coincided with higher DOC, protein amounts and a higher protein to carbohydrate ratio (Fig. 5a \& Table 5). Salinity as the 'marker' for the water mixing gradient was negatively
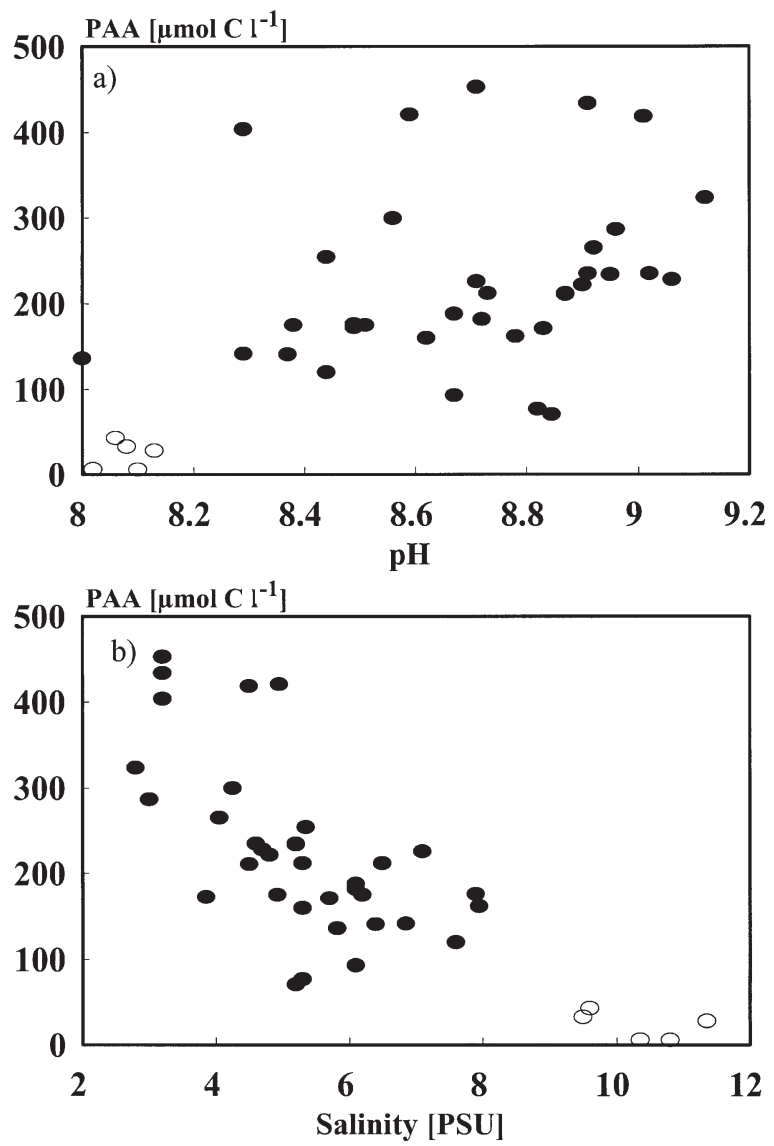

Fig. 5. Concentration of (a) particulate protein (PAA) [ $\mu$ mol C $\mathrm{l}^{-1}$ ] versus $\mathrm{pH}$ and (b) salinity [PSU] in plankton samples from Ahrenshoop (O) and the bodden stations ( $\bullet$ ). Spearman rank order correlation of the bodden data set for $\mathrm{pH}: \mathrm{r}_{\mathrm{s}}=0.41, \mathrm{p}=$ $0.015, \mathrm{n}=35$ and for salinity $\mathrm{r}_{\mathrm{s}}=-0.66, \mathrm{p}=0, \mathrm{n}=35$ 
Table 5. Spearman rank order correlations between abiotic parameters (salinity [PSU], $\mathrm{pH}$, temperature [ $\left.{ }^{\circ} \mathrm{C}\right]$, dissolved inorganic

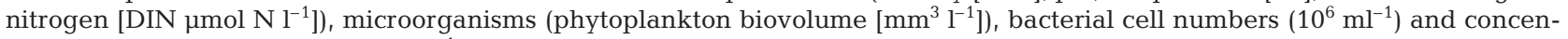

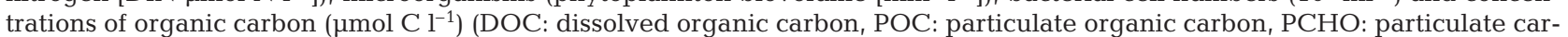
bohydrates, PAA: particulate protein), the C:N ratio, protein:carbohydrate ratio (PAA:PCHO) of POM ( $\mu \mathrm{mol} \mathrm{C} / \mu \mathrm{mol} \mathrm{C})$ and the portion of chemically unidentified POC (non-protein and non-carbohydrate, \%) with the correlation coefficient $\mathrm{r}_{\mathrm{s}}$, the probability p. ${ }^{*}$ Significant connection is assumed for $\mathrm{p}<0.05$ and the number of observations $\mathrm{n}$. Data of all bodden stations from April 22 to October 81996 were merged

\begin{tabular}{|c|c|c|c|c|c|c|c|c|c|}
\hline & \multicolumn{3}{|c|}{ Salinity } & \multicolumn{3}{|c|}{$\mathrm{pH}$} & \multicolumn{3}{|c|}{ Temperature } \\
\hline & $\mathrm{r}_{\mathrm{s}}$ & $\mathrm{p}$ & $\mathrm{n}$ & $\mathrm{r}_{\mathrm{s}}$ & $\mathrm{p}$ & $\mathrm{n}$ & $\mathrm{r}_{\mathrm{s}}$ & $\mathrm{p}$ & $\mathrm{n}$ \\
\hline DOC & $-0.46^{*}$ & 0.003 & 40 & $0.37^{*}$ & 0.019 & 40 & 0.20 & 0.244 & 35 \\
\hline POC & $-0.38^{*}$ & 0.026 & 35 & -0.17 & 0.328 & 35 & 0.16 & 0.398 & 30 \\
\hline $\mathrm{PCHO}$ & -0.13 & 0.460 & 35 & -0.24 & 0.172 & 35 & -0.04 & 0.831 & 30 \\
\hline PAA & $-0.66^{*}$ & 0 & 35 & $0.41^{*}$ & 0.015 & 35 & 0.28 & 0.129 & 30 \\
\hline Phytoplankton & -0.27 & 0.092 & 40 & -0.18 & 0.271 & 40 & -0.21 & 0.220 & 35 \\
\hline Bacteria & -0.08 & 0.608 & 40 & -0.18 & 0.260 & 40 & 0.17 & 0.334 & 35 \\
\hline $\mathrm{C}: \mathrm{N}$ & -0.16 & 0.438 & 24 & -0.31 & 0.138 & 24 & 0.18 & 0.448 & 19 \\
\hline \multirow[t]{3}{*}{ PAA:PCHO } & -0.23 & 0.186 & 35 & $0.40^{*}$ & 0.017 & 35 & 0.15 & 0.414 & 30 \\
\hline & & DIN & & \multicolumn{3}{|c|}{ Phytoplankton } & \multicolumn{3}{|c|}{ Bacteria } \\
\hline & $\mathrm{r}_{\mathrm{s}}$ & $\mathrm{p}$ & $\mathrm{n}$ & $\mathrm{r}_{\mathrm{s}}$ & $\mathrm{p}$ & $\mathrm{n}$ & $\mathrm{r}_{\mathrm{s}}$ & $\mathrm{p}$ & $\mathrm{n}$ \\
\hline DOC & 0.26 & 0.109 & 40 & 0.10 & 0.535 & 40 & 0.17 & 0.290 & 40 \\
\hline POC & $0.40^{*}$ & 0.017 & 35 & $0.51^{*}$ & 0.002 & 35 & $0.59^{*}$ & 0 & 35 \\
\hline $\mathrm{PCHO}$ & 0.31 & 0.070 & 35 & $0.56^{*}$ & 0 & 35 & $0.54^{*}$ & 0 & 35 \\
\hline PAA & 0.29 & 0.093 & 35 & 0.26 & 0.132 & 35 & 0.20 & 0.249 & 35 \\
\hline Phytoplankton & 0.31 & 0.055 & 40 & - & & & - & & \\
\hline Bacteria & 0.28 & 0.078 & 40 & - & & & - & & \\
\hline $\mathrm{C}: \mathrm{N}$ & $0.44^{*}$ & 0.032 & 24 & $0.58^{*}$ & 0.003 & 24 & 0.39 & 0.062 & 24 \\
\hline PAA:PCHO & -0.11 & 0.519 & 35 & $-0.37^{*}$ & 0.027 & 35 & $-0.37^{*}$ & 0.028 & 35 \\
\hline \multicolumn{2}{|c|}{ Chem. unidentified } & Not tested & & 0.12 & 0.478 & 35 & $0.35^{*}$ & 0.039 & 35 \\
\hline
\end{tabular}

correlated to POC and DOC and, even stronger, to particulate protein (Fig. 5b). There were positive correlations between DIN and POC or the C:N ratio of POM. For the quantity of particulate carbohydrates none of the abiotic factors seemed to be significant.

Neither the phytoplankton biovolumes nor bacterial abundances were correlated to any of the investigated abiotic parameters during late spring and summer. Although particulate protein is a relatively labile POM fraction and could, therefore, be correlated to microbial biomass, there was no such correlation (Table 5). Phytoplankton as the dominant biomass in the bodden system, but also bacteria, increased significantly with POC and particulate carbohydrates. The increase of the chemically unidentified portion of POC with the POC concentration (Fig. 6a) complicates interpretations of co-occurrences between POC and biological parameters (Table 5). The dominating biomass components, bacteria and phytoplankton, were correlated $\left(\mathrm{r}_{\mathrm{s}}=0.44, \mathrm{p}=0.005, \mathrm{n}=40\right.$; cf. Fig. 7).

Total volume of non-transparent particles correlated with POC, but not with PAA or PCHO (Table 6). This suggests a fairly constant organic content of particulate matter, but also reflects the changing POM composition with POC accumulation. The volume of organic particles (PI and DTAF) both correlated significantly with the concentration of particulate protein, but not with particulate carbohydrates. Phytoplankton volumes greater than total non-transparent particle volumes were observed in 5 out of 40 samples. Special species dominances, e.g. by hyaline algae species, perhaps 'overlooked' by the image analysis program, were not detected. Although phytoplankton was the dominating biomass component and increased with higher total particle volumes $\left(\mathrm{r}_{\mathrm{s}}=0.38, \mathrm{P}=0.015, \mathrm{n}=40\right)$, its volume contribution was significantly negatively correlated $\left(\mathrm{r}_{\mathrm{s}}=-0.73, \mathrm{P}=0, \mathrm{n}=40\right.$ ) to particulate volume (Fig. 6b). Therefore, high particle volumes cannot be explained alone by increased phytoplankton biovolume or its succession through spring and summer.

\section{DISCUSSION}

\section{POM composition in the eutrophic bodden system}

Since during the growth season inorganic nutrients are near the detection limit, salinity functions as the (mathematical) reference line for freshwater influence and eutrophication (cf. also Fichez et al. 1993). While DOC, POC and particulate protein were significantly negatively correlated to salinity, neither particulate 
a) unidentified residue [\%]

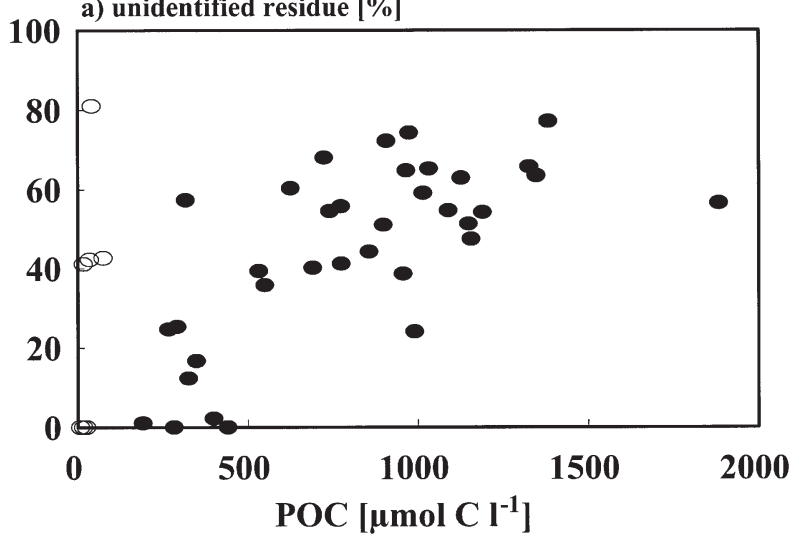

b) contribution of phytoplankton [\%]

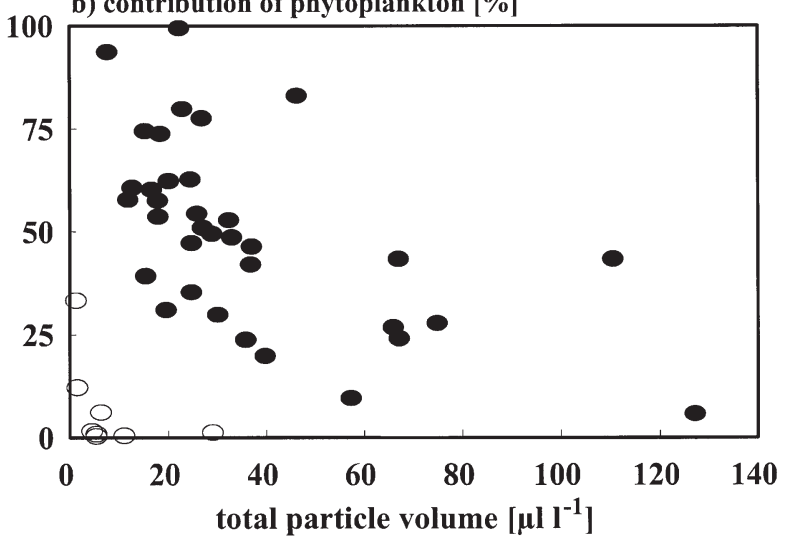

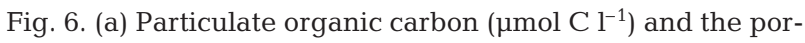
tion of chemically unidentified residue of POC (non-carbohydrate or protein) $(\%): r_{s}=0.65, p=0, n=35$. (b) Total particle volume determined by image analysis using transmission microscopy $\left(\mu l \mathrm{l}^{-1}\right)$ and contribution of phytoplankton biovolume $(\%): \mathrm{r}_{\mathrm{s}}=-0.73, \mathrm{p}=0, \mathrm{n}=40$ in plankton samples from Ahrenshoop (O) and the bodden stations (๑). Spearman rank order correlation only of the bodden data set

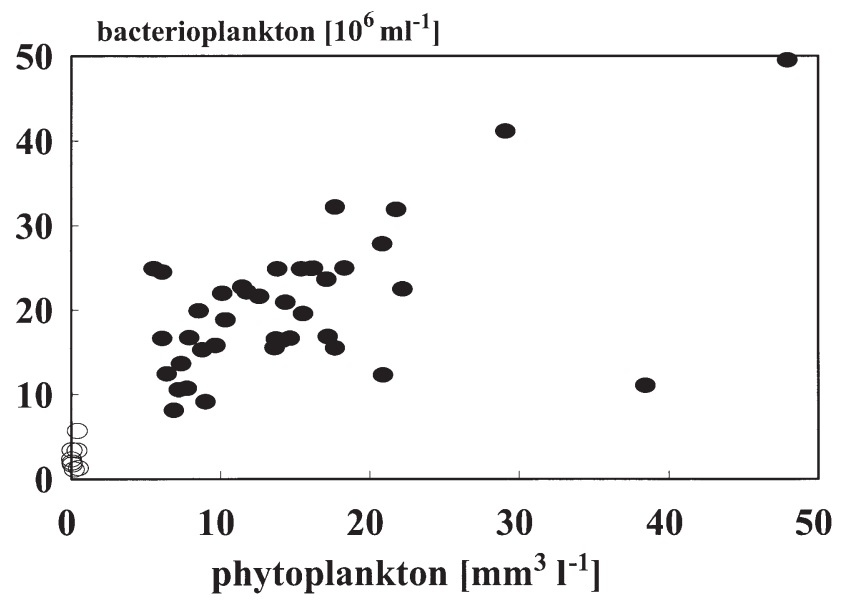

Fig. 7. Phytoplankton biovolume $\left(\mathrm{mm}^{3} \mathrm{l}^{-1}\right)$ and bacterial cell numbers $\left(10^{6} \mathrm{ml}^{-1}\right)$ in plankton samples from Ahrenshoop (O) and the bodden stations $(\bullet)$. Spearman rank order correlation of the bodden data set: $\mathrm{r}_{\mathrm{s}}=0.44, \mathrm{p}=0.005, \mathrm{n}=40$ carbohydrates nor the investigated microorganism biomasses followed the water mixing gradient. This confirms earlier observations by Revelante \& Gilmartin (1992) in the Adriatic Sea at a station with a riverine input. Average POC concentrations differed significantly between certain bodden basins (cf. Table 1) and always between the bodden and the Baltic Sea station in spite of all the variance deriving from hydrodynamics, sedimentation and resuspension. In the inner parts of the bodden system the DOC:POC ratio was 1:1 (cf. Schiewer et al. in press), which is an unusual pattern for aquatic systems (Eisma 1993). Except for some rivers with high POC concentrations (e.g. Depetris \& Kempe 1993), there are only few reports of such a low DOC:POC ratio, for example in the Eastern Harbour of Alexandria with an average of 2.5:1 (Abdel Moati et al. 1991) or 3:1 in a salt marsh (Roman \& Deiber 1989). While in all these distinct systems high POC loads were the result of allochthonous input, this seems not to be the case for the Darß-Zingst bodden chain. Here, at least the riverine input is very small providing only $10 \%$ of water influx (Schlungbaum et al. 1994a) and the river's POC concentrations, although measured only occasionally, were always much lower than in the bodden system (S. Görs unpubl.). Thus, the high POM load can only originate from pelagic primary production, resuspension of fluffy sediment layer material or perhaps from macrophytes. The last potential source of POM does not play a role until October, when submerse macrophytes and reed begin to die.

The carbohydrate constituent of POM correlated with phytoplankton biomass, as often observed in other waters (e.g. Fabiano et al. 1993, Striquer-Soares \& Chevolot 1996). Protein correlated significantly with phytoplankton only under certain circumstances and not as well as carbohydrates. Such distinct periods involved a phytoplankton bloom (Jónasdóttir et al. 1995) or important freshwater influxes (Grange \& Allanson 1995). In the central North Pacific gyre, Cho \& Azam (1990) reported a positive correlation between bacterial biomass and POC, which is in good agreement with the data presented here. We also found a positive relationship between bacteria and POC (Table 5) with 10-times higher POC concentrations and with bacterial biomasses amounting only to a very small fraction of POM (cf. Table 2 \& Fig. 4). The cooccurrence of bacterial biomass and POM as well as their joint development with phytoplankton (Schumann \& Schiewer 1994, Fig. 7) seem to indicate a dependence of bacteria on their food source even in this eutrophic bodden system. In the above-mentioned gyre, a switch from phytoplankton biomass dominance in meso- to eutrophic regions to bacterial superiority in the most oligotrophic parts was observed. Similar to that, the bacterial biomass exceeded phytoplankton in 
Table 6. Spearman rank order correlation matrix of particulate matter concentrations $\left(\mu m o l l^{-1}\right)$ and different particle volumes $\left(\mu \mathrm{l} \mathrm{l}^{-1}\right.$ ) (POC: particulate organic carbon, PCHO: particulate carbohydrates, PAA: particulate protein, carbon converted biomass of phyto-, bacterio- and protozooplankton, CC: volume of non-conducting, NT: non-transparent, PI: nucleic acid-containing and DTAF: particles out of carbohydrates and protein, biovolume: sum of all microorganisms) with the correlation coefficient $\mathrm{r}_{\mathrm{s}}$, the probability $\mathrm{p}\left({ }^{*}\right.$ significant connection is assumed for $\left.\mathrm{p}<0.05\right)$ and the number of observations $\mathrm{n}$. Data of all bodden stations from April 22 to October 81996 were merged

\begin{tabular}{|c|c|c|c|c|c|c|c|c|c|c|c|c|}
\hline & \multicolumn{3}{|c|}{ POC } & \multicolumn{3}{|c|}{ PCHO } & \multicolumn{3}{|c|}{ PAA } & \multicolumn{3}{|c|}{ Biovolume } \\
\hline & $\mathrm{r}_{\mathrm{s}}$ & $\mathrm{p}$ & $\mathrm{n}$ & $\mathrm{r}_{\mathrm{s}}$ & $\mathrm{p}$ & $\mathrm{n}$ & $r_{s}$ & $\mathrm{p}$ & $\mathrm{n}$ & $\mathrm{r}_{\mathrm{s}}$ & $\mathrm{p}$ & $\mathrm{n}$ \\
\hline $\mathrm{CC}$ & 0.27 & 0.319 & 15 & 0.32 & 0.240 & 15 & 0.26 & 0.346 & 15 & $0.51^{*}$ & 0.021 & 20 \\
\hline NT & $0.48^{*}$ & 0.004 & 35 & 0.27 & 0.121 & 35 & 0.21 & 0.231 & 35 & $0.42^{*}$ & 0.007 & 40 \\
\hline PI & $0.59^{*}$ & 0 & 35 & -0.07 & 0.674 & 35 & $0.58^{*}$ & 0 & 35 & 0.22 & 0.174 & 40 \\
\hline DTAF & 0.05 & 0.769 & 35 & -0.09 & 0.604 & 35 & $0.50^{*}$ & 0.002 & 35 & 0.16 & 0.309 & 40 \\
\hline Biovolume & $0.57^{*}$ & 0 & 35 & $0.60^{*}$ & 0 & 35 & 0.32 & 0.063 & 35 & & & \\
\hline
\end{tabular}

most samples at the mesotrophic Baltic Sea coast station, and phytoplankton strongly dominated microbial biomass in the eutrophic bodden samples (Table 2).

The contribution of phytoplankton to POM (18\%) in the boddens was rather low if compared to other systems (e.g. a river: Admiraal et al. 1992, the eutrophic Bay of Biscay: Bode \& Fernández 1992, a eutrophic lake: Søndergaard et al. 1995). It was similar to an equally shallow lagoon at the coast of the Mediterranean Sea, where only $13 \%$ of energy was available through phytoplankton (Pusceddu et al. 1996). Because other planktonic microorganisms contributed even less to total biomass, the 'non-organism' POM contributed $75 \%$ in the bodden chain, a value rarely observed (Simon et al. 1990). This high and persistent amount of detritus probably masks temporal developments or spatial differences, so that further conclusions on connections between eutrophication status or salinity and the importance of detritus in the Darß-Zingst bodden chain could not be drawn. Therefore, more attention has to be given to this quantitatively important carbon compartment, especially in carbon budgets or matter cycling models.

There are many data on protein portions, and C:N and protein:carbohydrate ratios, because protein is the most readily degraded component of POM (Cauwet 1981) and therefore indicates its degradation status. However, these markers of nitrogen availability alone do not seem to be sufficient for comparisons of different systems, because especially in estuaries these values are extraordinarily highly variable (Table 7). In comparison to marine photic zones the samples from the Darß-Zingst boddens have high $\mathrm{C}: \mathrm{N}$ ratios and low protein contents resembling more the quality of sediment trap material (Colombo et al. 1996). Obviously, high amounts of resuspended material from the sediment surface were always present in the pelagial of the boddens. The frequent strong winds induce the complete mixing of the only $2 \mathrm{~m}$ high water column (Schubert et al. 1997) causing important resuspension and lateral transport processes of particulate matter.
The load of chemically unidentified material-in most cases defined as the POC less carbohydrates, protein and lipids - is highly variable in different systems from $17 \%$ in the Mediterranean Sea (Fichez 1991) to $90 \%$ in the highly eutrophic Great Ouse Estuary (Fichez et al. 1993). In the bodden samples, large portions of non-protein and non-carbohydrate organic material of up to $77 \%$ occurred at higher POC concentrations (cf. Figs 3b \& 6a). The other major class of biopolymers, on which unfortunately we do not have data, are lipids. With some exceptions (e.g. Kreeger et al. 1997), however, lipids seem to represent a less important 'bulk' biopolymer group accounting only for $7 \%$ of POC in the photic and $11 \%$ in the aphotic zones of Ross Sea, Antarctica (Fabiano et al. 1993). They are 3 to 7 times less concentrated than protein in the North Sea (Lardinois et al. 1995). Other chemical classes, considered as at least temporary important constituents of POC, were ATP (4 to $36 \%$ in Terra Nova Bay, Fabiano et al. 1995), chitin (24 to 45-times lower concentrations than protein, Lardinois et al. 1995) or nucleic acids (8-times lower than protein at sea surface in the Cretan Sea, Dell'Anno et al. 1999). Based on these published rather low concentrations and from the inclusion of chitin and parts of ATP and nucleic acids in our carbohydrate measurements, we cannot explain the high amounts and nature of chemically unidentified POM.

\section{Quantification of detritus and mucoid material by image analysis}

The high percentages of chemically unidentified POM with a probable poor quality represents an immense accumulation of inactive and refractory forms. Such material can play an important role as settling substrate for bacteria and small protozoa (Zimmermann \& Kausch 1996, Azam 1998) and influence physical and chemical properties of POM, e.g. its sink- 
Table 7. C:N ratios, protein portions (\%) and protein to carbohydrate relations of marine, limnetic and estuarine sampling sites ranged in accordance to maximal observed POC concentrations $\left(\mu \mathrm{g}^{-1}\right)$

\begin{tabular}{|c|c|c|c|c|c|c|}
\hline & Characteristics & $\begin{array}{l}\text { Max. POC } \\
\left(\mu \mathrm{l} \mathrm{l}^{-1}\right)\end{array}$ & $\mathrm{C}: \mathrm{N}$ & $\begin{array}{c}\text { Protein } \\
\text { g Prot/g POC (\%) }\end{array}$ & $\begin{array}{c}\text { Protein:Carbohydrates } \\
(\mu \mathrm{g} / \mu \mathrm{g})\end{array}$ & Source \\
\hline \multicolumn{7}{|l|}{ Marine } \\
\hline \multirow[t]{2}{*}{ Mediterranean } & Darkness & са 100 & 10.2 & 46 & 0.46 & Fichez (1991) \\
\hline & Cave entrance & са 220 & 7.6 & 48 & 0.48 & \\
\hline Terra Nova & Below mixed layer & 115 & $5.2-14.6$ & 37 & $0.5-5.9$ & Fabiano et al. (1996) \\
\hline Bay & Mixed layer & 471 & $5.4-6.8$ & 46 & $0.4-3.8$ & \\
\hline \multirow[t]{2}{*}{ Ross Sea } & Aphotic zone & 300 & $5.2-19.8$ & 18 & $0.1-3.4$ & Fabiano et al. (1993) \\
\hline & Photic zone & 653 & $5.4-9.1$ & 33 & $0.3-3.3$ & \\
\hline Baltic Sea coast & Mesotrophic & 900 & $7.4-8.4$ & 57 & $0.5-5.6(\mathrm{~mol} \mathrm{C} / \mathrm{mol} \mathrm{C})$ & This study \\
\hline Yaldad Bay & Tidal flat & 2500 & $4-11$ & >40 (organic seston) & & Navarro et al. (1993) \\
\hline Kinu-ura Bay & Eutrophic & 3600 & $4.6-7.4$ & $25-42$ & $1.0-5.1$ & Hama \& Handa (1994) \\
\hline Salt pond & Marine & 10000 & & $5-13$ & & Lohrenz et al. (1987) \\
\hline Bay of Bengal & River influenced & & & & $1.7-3.5$ & Sreepada et al. (1996) \\
\hline \multicolumn{7}{|l|}{ Limnetic } \\
\hline Tama River & & 1950 & & $29-37$ & & Ochiai et al. (1988) \\
\hline Waynewood & Eutrophic epilimnion & 3611 & $20-60$ & & $<0.5$ & Kreeger et al. (1997) \\
\hline Lobo Reservoir & Oligotrophic & 3750 & & $3-13$ & $0.2-1.3$ & $\begin{array}{l}\text { Striquer-Soares \& } \\
\text { Chevolot (1996) }\end{array}$ \\
\hline Lake Aydat & Eutrophic & & & & $0.5-1.0$ & Aleya (1992) \\
\hline Villerest Reservoir & Hypereutrophic & & & & $0.8-4.1$ & Michard et al. (1996) \\
\hline \multicolumn{7}{|l|}{ Estuarine } \\
\hline \multirow[t]{3}{*}{ Loire Estuary } & Marine site & 1320 & & $3-63$ & & Relexans et al. (1988) \\
\hline & Turbidity max & 30400 & & $16-49$ & & \\
\hline & River site & 6770 & & $17-54$ & & \\
\hline $\begin{array}{l}\text { Great Ouse } \\
\text { Estuary }\end{array}$ & Highly eutrophic & $\begin{array}{l}\text { Marine: } 1984 \\
\text { River: } 6763\end{array}$ & & & $\begin{array}{l}0.6-2.4 \text { spring/summer } \\
0.5-1.9 \text { autumn/winter }\end{array}$ & Fichez et al. (1993) \\
\hline Darß-Zingst bod. & Hypereutrophic & 22600 & $8.6-15.4$ & $22(11-78)$ & $0.4-9.0(\mathrm{~mol} \mathrm{C} / \mathrm{mol} \mathrm{C})$ & This study \\
\hline $\begin{array}{l}\text { Lower St. Lawrence } \\
\text { Estuary }\end{array}$ & $\begin{array}{l}\text { Sediment trap } \\
\text { material }\end{array}$ & 66900 (DW) & $8.2-11.1$ & 8-16 (TOC) & & Colombo et al. (1996) \\
\hline
\end{tabular}

ing velocity and aggregation potential (Logan et al. 1995).

To elucidate the nature of those parts of POM, a variety of detailed microscopical particle analyses were made. Since the break down of nucleic acids can progress slowly, especially when cellular components (Dupray et al. 1997) or a viral envelope (Tsai et al. 1995) protect nucleic acids against nuclease activity, all nucleic acid-containing particles (PI) were assumed to be living organisms, dead cells or at least residues of them. Thus, the volume of all nucleic acids-containing particles, which were not identified as microorganisms, was assigned to the detritus pool (cf. Fig. 1). However, except for the protozoan live counts we do not have data on the contribution of dead algae to the Lugol fixed phytoplankton counts. Neither do we have data on dead bacteria inclusion in the estimation of DAPI-stained cell numbers. Concerning the differentiation of living, active, inactive and/or dead bacteria, numerous approaches have been used in the past years. They revealed important counts of DAPI-stainable but probably not living bacteria or bacteria at all (non-nucleoid-containing bacte- ria: Zweifel \& Hagström 1995; cells, which do not hybridise with a general eubacteria probe: Karner \& Fuhrman 1997; not respiring bacteria: Rodriguez et al. 1992; cells with permeable membranes: Roth et al. 1997). Because all these methods are rather timeconsuming and/or expensive and have to be conducted immediately after sampling, in this study all bacteria-shaped and DAPI-stainable objects had to be assigned as (living) bacterial biomass, which in this respect is overestimated. Algae, which were obviously without cell contents were not counted, but we cannot exclude a certain contribution of dead cells to (living) phytoplankton which actually belong to the compartment detritus. Because of our definition and the applied methods, detritus consisted of only very degraded dead (micro)organisms of irregular shape, empty algal cells or macrophyte-derived particles and is clearly underestimated. A variety of particles addressed by other authors as detritus (for a discussion of theoretically needed and practically used definitions, cf. Velimirov 1991) were not considered or intentionally excluded, as was done with the mucoid material. 
The volume of mucoid material as the difference between organic particles (DTAF) and nucleic acidcontaining particles (PI) (cf. Fig. 1) dominated with 63\% the total organic particle volume in the bodden chain, but accounted for only $31 \%$ of organic volume in $\mathrm{AH}$ (cf. Fig. 4). If this holds true, the mass of mucoid material cannot be estimated without the knowledge of the matter contents or density of different particle types and sizes. Abiotic factors, e.g. pH and salinity, especially influence the density of mucoid particles. Nevertheless, we could measure much higher concentrations of POC, particulate carbohydrates and protein as well as total organic particle's volume in the bodden as compared to the Baltic Sea (cf. Fig. 3b \& Table 4). The increase of POC and protein with salinity even within the estuarine system was significant (cf. Table 5). Thus, the high amount of mucoid particles volume should reflect high masses of transparent (exo)polymeric particles (TEP). The importance of TEPs is now well recognised for many aquatic systems (e.g. Alldredge et al. 1993, Zimmermann \& Kausch 1996). However, estimating their contribution to organic particle volume is only possible if we can compare volumes of TEP with other particle types, as we have tried to do in this paper. Like our results, Mari \& Burd (1998) proved the quantitative dominance of TEPs by the fact that TEPs volume could be $>2$ orders of magnitude higher than phytoplankton biovolume. However, the abundance of TEPs as the only indicator for their quantitative importance may be biased by the detection method, especially the detection limit for the very abundant small particles (Mari \& Burd 1998). Because small particles do not influence the total volume significantly (cf. Table 3), estimates of TEPs importance should be given at least on a particle's volume basis, unless it is possible to measure densities and the carbon or carbohydrate contents of particles (Mari 1999).

The lack of correlation between DTAF-stainable volume, i.e. all protein- and carbohydrate-containing objects, and carbohydrates (cf. Table 8) indicates that organic particles had very different densities. This assumption is strengthened by the absence of a correlation between particulate carbohydrates and nearly all particle parameters (cf. Table 5). Aggravating, organic material does not only consist of different particle types, such as organisms and mucoid polymers, but there is evidence of a strong size-dependent change in carbon content of TEPs (Mari 1999). Because intact cells give an appropriate signal in electronic particle counters, but dead or mucoid material can be underestimated by up to $70 \%$ (Boyd \& Johnson 1995), the Coulter ${ }^{\circledR}$ Counter derived only the expected correlation between total particle volume and total (living) biovolume. The contribution of phytoplankton to non-transparent and organic particles dropped with increasing particle volume (cf. Fig. 6b). Therefore, amorphous and mucoid material must have accumulated as well as chemically unidentified organic material with increasing seston amounts (cf. Fig. 6a). A similar accumulation of transparent exopolymeric particles from spring through summer was found in the Southern coastal Kattegat (Mari \& Burd 1998). The authors concluded that TEP originated from primary production and accumulated thereafter because of a low nutrient status in the pelagial.

However, whether the mucoid were distinct particles or components of aggregates could not be shown, since each staining procedure and analysis was conducted on separate subsamples. This was done in order to exclude propidium iodide leakage into the green image, which could not be corrected sufficiently by the applied optical filter sets and the black and white detection camera. The differential analysis of the same frames with different excitation wavelength was theoretically possible, but would have required an enormous calculation effort. Regarding the additional problems connected with volume calculation from 2D image analysis data (Schumann \& Rentsch 1998), such exertion should only be accepted with good raw data from a confocal laser scanning microscope. Besides the real 3-dimensional reconstruction of the particle structure, the strong laser excitation, the electronic detection of very low light signals (photon counting) and the reproducible threshold settings for each (simultaneously) detected fluorescence of different stains provide promising tools for further investigations of detrital and mucoid components of seston particles and aggregates in aquatic systems.

Acknowledgements. We are very grateful to 2 anonymous referees for their detailed and very helpful remarks and proposals on an earlier version of this manuscript. We would also like to thank Thorsten Rieling and Ulf Karsten for their critical comments on the paper. We thank Marianne Müller for her technical assistance in chemical analyses and Michael Kuhn for linguistic improvements of the manuscript. The work was financially supported by the Ministry of Education, Science, Technology and Research (BEO 71/03F0161W) and the Graduiertenkolleg 'Integrative analysis of tideless shallow estuaries' promoted by the Deutsche Forschungsgemeinschaft.

\section{LITERATURE CITED}

Abdel Moati AR, Aboul Kassim TA, Dowidar NM, El Nady FE (1991) Carbon fractionation and balance in the Eastern Harbour of Alexandria, Egypt. J Coast Res 7:377-386

Admiraal W, Jacobs DMLHA, Breugem P, De Ruyter Van Steveninck ED (1992) Effects of phytoplankton on the elemental composition $(C, N, P)$ of suspended particulate material in the lower River Rhine. Hydrobiologia 235/236: 479-489

Aleya L (1992) The seasonal succession of phytoplankton in an eutrophic lake through the coupling of biochemical 
composition of particulates, metabolic parameters and environmental conditions. Arch Hydrobiol 124:69-88

Alldredge AL, Passow U, Logan BE (1993) The abundance and significance of a class of large, transparent organic particles in the ocean. Deep-Sea Res 40:1131-1140

Azam F (1998) Microbial control of oceanic carbon flux: the plot thickens. Science 280:694-969

Bode A, Fernández E (1992) Variability of biochemical composition and size distributions of seston in the euphotic zone of the Bay of Biscay: implications for microplankton trophic structure. Mar Biol 114:147-155

Boyd CM, Johnson GW (1995) Precision of size determination of resistive electronic particle counters. J Plankton Res 17: 41-58

Burney CM, Sieburth JMcN (1977) Dissolved carbohydrates in seawater II, A spectrophotometric procedure for total carbohydrate analysis. Mar Chem 5:15-28

Cauwet G (1981) Non-living particulate matter. In: Duursma EK, Dawson R (eds) Marine organic chemistry. Elsevier, Amsterdam, p 71-89

Cho BC, Azam F (1990) Biogeochemical significance of bacterial biomass in the ocean's euphotic zone. Mar Ecol Prog Ser 63:253-259

Colombo JC, Silverberg N, Gearing JN (1996) Biogeochemistry of organic matter in the Laurentian Trough. 1. Composition and vertical fluxes of rapidly settling particles. Mar Chem 51:277-293

Dale T, Burkill PH (1982) Live counting - a quick and simple technique for enumerating pelagic ciliates. Annales de L' Inst Oceanogr 58:267-276

Dell'Anno A, Marrale D, Pusceddu A, Fabiano M, Danovaro R (1999) Particulate nucleic acid dynamics in a highly oligotrophic system: The Cretan Sea (Eastern Mediterranean). Mar Ecol Prog Ser 186:19-30

Depetris PJ, Kempe S (1993) Carbon dynamics and sources in the Parana River. Limnol Oceanogr 38:382-395

Duarte CM, Benavent E, Del Carmen Sánchez M (1999) The microcosm of particles within seagrass Posidonia oceanica canopies. Mar Ecol Prog Ser 181:289-295

Dupray E, Caprais MP, Derrien A, Fach P (1997) Salmonella DNA persistence in natural seawaters using PCR analysis. J Appl Microbiol 82:507-510

Edler L (ed) (1979) Recommendations on methods for marine biological studies in the Baltic Sea. Phytoplankton and chlorophyll. The Baltic Marine Biologists Publication 5

Eisma D (1993) Suspended matter in the aquatic environment. Springer, Berlin

Fabiano M, Povero P, Danovaro R (1996) Particulate organic matter composition in Terra Nova Bay (Ross Sea, Antarctica) during summer 1990. Antarct Sci 8:7-13

Fabiano M, Pusceddu A (1998) Total and hydrolizable particulate organic matter (carbohydrates, proteins and lipids) at a coastal station in Terra Nova Bay (Ross Sea, Antarctica). Polar Biol 19:125-132

Fabiano M, Povero P, Danovaro R (1993) Distribution and composition of particulate organic matter in the Ross Sea (Antarctica). Polar Biol 13:525-533

Fabiano M, Danovaro R, Crisafi E, La Ferla R, Povero P, Acosta-Pomar L (1995) Particulate matter composition and bacterial distribution in Terra Nova Bay (Antarctica) during summer 1989-1990. Polar Biol 15:393-400

Fichez R (1991) Suspended particulate organic matter in a Mediterranean submarine cave. Mar Biol 108:167-174

Fichez R, Dennis P, Fontaine MF, Jickells TD (1993) Isotopic and biochemical composition of particulate organic matter in a shallow water estuary (Great Ouse, North Sea, England). Mar Chem 43:263-276
Galois R, Richard P, Fricourt B (1996) Seasonal variations in suspended particulate matter in the Marennes-Oleron Bay, France, using lipids as biomarkers. Estuar Coast Shelf Sci 43:335-357

Gewässergütebericht Mecklenburg-Vorpommern (1996/1997) Zustand der Gewässergüte von Fließ-, Stand- und Küstengewässern und der Grundwasserbeschaffenheit in Mecklenburg-Vorpommern. Hrsg. Umweltministerium Mecklenburg-Vorpommern

Grange N, Allanson BR (1995) The influence of freshwater inflow on the nature, amount and distribution of seston in estuaries of the eastern Cape, South Africa. Estuar Coast Shelf Sci 40:403-420

Grasshoff K, Ehrhardt M, Kremling K (eds) (1983) Methods of seawater analysis. Verlag Chemie, Weinheim

Hama J, Handa N (1994) Variability of the biomass, chemical composition and productivity of phytoplankton in Kinuura Bay, Japan during the rainy season. Estuar Coast Shelf Sci 39:497-509

Heerkloß R, Vietinghoff U (1981) Biomasseäquivalente planktischer und benthischer Organismen in den Darß-Zingster Boddengewässern. Wiss Z Univ Rostock 30: 31-36

Hernes PJ, Hedges JI, Peterson ML, Wakeham SG, Lee C (1996) Neutral carbohydrate geochemistry of particulate material in the Central Equatorial Pacific. Deep Sea Res II 43:1181-1204

Hubberten U (1994) Aminosäuren und Huminstoffe im Stickstoffkreislauf polarer Meere. Ber Polarforsch 153:123

Jónasdóttir SH, Fields D, Pantoja S (1995) Copepod egg production in Long Island Sound, USA, as a function of the chemical composition of seston. Mar Ecol Prog Ser 119: 87-98

Karner M, Fuhrman JA (1997) Determination of active marine bacterioplankton: a comparison of universal 16S rRNA probes, autoradiography, and nucleoid staining. Appl Environ Microbiol 63:1208-1213

Klinkenberg G, Schumann R (1995) Abundance changes of autotrophic and heterotrophic picoplankton in the Zingster Strom, a shallow, tideless estuary south of the DarßZingst Peninsula (Southern Baltic Sea). Arch Hydrobiol 134:359-377

Kreeger DA, Goulden CE, Kilham SS, Lynn SG, Datta S (1997) Seasonal changes in the biochemistry of lake seston. Freshw Biol 38:539-554

Lardinois D, Eisma D, Chen S (1995) Seasonal differences in concentrations of particulate lipids, proteins and chitin in the North Sea. Neth J Sea Res 33:147-161

Lindroth P, Mopper K (1979) High performance liquid chromatographic determination of subpicomole amounts of amino acids by precolumn fluorescence derivatisation with o-phthaldialdehyde. Anal Chem 51:1667-1674

Logan BE, Passow U, Alldredge AL, Grossart HP, Simon M (1995) Rapid formation and sedimentation of large aggregates is predictable from coagulation rates (half-lives) of transparent exopolymer particles (TEP). Deep-Sea Res 42: 203-214

Lohrenz SE, Taylor CD, Howes BL (1987) Primary production of protein: II. Algal protein metabolism and its relation to particulate organic matter composition in the surface mixed layer. Mar Ecol Prog Ser 40:175-183

Lund WS, Kipling C, LeCren ED (1958) The inverted microscope method of estimating algal numbers and the statistical basis of estimations by counting. Hydrobiologia 11: 144-170

Mari X (1999) Carbon content and C:N ratio of transparent exopolymeric particles (TEP) produced by exudates of diatoms. Mar Ecol Prog Ser 183:59-71

Mari X, Burd A (1998) Seasonal size spectra of transparent 
exopolymeric particles (TEP) in a coastal sea and comparison with those predicted using coagulation theory. Mar Ecol Prog Ser 163:63-76

Michard M, Aleya L, Verneaux J (1996) Mass occurrence of the Cyanobacteria Microcystis aeruginosa in the hypereutrophic Villerest Reservoir (Roanne, France): usefulness of the biyearly examination of N/P (nitrogen phosphorus) and P/C (protein/carbohydrate) couplings. Arch Hydrobiol 135:337-359

Navarro JM, Clasing E, Urrutia G, Asencio G, Stead R, Herrera $C$ (1993) Biochemical composition and nutritive value of suspended particulate matter over a tidal flat of southern Chile. Estuar Coast Shelf Sci 37:59-73

Nausch G, Schlungbaum G (1991) Eutrophication and restoration measures in the Darß-Zingst Bodden Chain. Int Revue Ges Hydrobiol 76:451-463

Ochiai M, Ogino M, Sasaki K, Okazawa T (1988) Behavior or particulate carbohydrates and amino acids in the estuary of the Tama River. Mar Chem 25:265-278

Porter KG, Feig YS (1980) The use of DAPI for counting and identifying aquatic microflora. Limnol Oceanogr 25:943-948

Pusceddu A, Serra E, Sanna O, Fabiano M (1996) Seasonal fluctuations in the nutritional value of particulate organic matter in a lagoon. Chem Ecol 13:21-37

Relexans JC, Meybeck M, Billen G, Brugeaille M, Etcheber $\mathrm{H}$, Somville $M$ (1988) Algal and microbial processes involved in particulate organic matter dynamics in the Loire estuary. Estuar Coast Shelf Sci 27:625-644

Revelante N, Gilmartin M (1992) The lateral advection of particulate organic matter from the Po delta region during summer stratification, and its implications for the northern Adriatic. Estuar Coast Shelf Sci 35:191-212

Rieling T, Gerbersdorf S, Stodian I, Black HJ, Dahlke S, Köster M, Meyercordt J, Meyer-Reil LA (2000) Benthic microbial decomposition of organic matter and nutrient fluxes at the sediment-water interface in a shallow coastal inlet of the southern Baltic Sea (Nordrügensche Bodden). In: Flemming BW, Delafontaine MT, Liebezeit G (eds) Muddy coasts - processes and products. Elsevier Oceanography Book Series, SCOR WG 106

Rieling T, Stodian I, Black HJ, Köster M, Meyer-Reil LA (1999) Aspekte des mikrobiellen Kohlenstoffkreislaufs. Bodden 8:49-57

Rodriguez GG, Phipps D, Ishiguro K, Ridgway HF (1992) Use of a fluorescent redox probe for direct visualization of actively respiring bacteria. Appl Environ Microbiol 58: 1801-1808

Roman CT, Daiber FC (1989) Organic carbon flux through a Delaware Bay salt marsh: tidal exchange, particle size distribution, and storms. Mar Ecol Prog Ser 54:149-156

Roth BL, Poot M, Yue ST, Millard PJ (1997) Bacterial viability and antibiotic susceptibility testing with SYTOX green nucleic acid stain. Appl Environ Microbiol 63:2421-2431

Schiewer U (1998) 30 Years' eutrophication in shallow brackish waters - lessons to be learned. Hydrobiologia 363: 73-79

Schiewer U, Rentsch D, Schumann, R (in press) Composition and size fractions of particulate material in the polytrophic Darss-Zingst lagoon and coastal area of the southern Baltic Sea. Proc Internat Assoc Theor A App Limnol

Schlungbaum G (1997) Die Bewertung der inneren Küstengewässer der Ostsee in Mecklenburg-Vorpommern ein Beitrag zum Gewässergüteatlas der Bundesrepublik Deutschland mit Vergleichen zu den fließenden und stehenden Gewässern. Rostock Meeresbiol Beitr 5:9-35

Schlungbaum G, Baudler H, Nausch G (1994a) Die DarßZingster Boddenkette - ein typisches Flachwasserästuar an der südlichen Ostseeküste. Rostock Meeresbiolog Beitr $2: 5-26$

Editorial responsibility: Otto Kinne (Editor),

Oldendorf/Luhe, Germany
Schlungbaum G, Nausch G, Baudler H (1994b) Sedimentstruktur und Sedimentdynamik in den Darß-Zingster Boddengewässern. Rostock Meeresbiolog Beitr 2:27-40

Schlungbaum G, Schiewer U, Arndt EA (1994c) Sanierung und Bewirtschaftung der Darß-Zingster Boddengewässer als Teil der Küstengewässer Mecklenburg-Vorpommerns. Rostock Meeresbiolog Beitr 2:203-213

Schubert H, Forster RM, Schoor A, Ockenfeld K (1997) Horizontale und vertikale Chlorophyllverteilung des Bodstedter Boddens. Rostock Meeresbiol Beitr 5:69-84

Schumann R (1993) Zur Rolle des Pico- und Nanophytoplanktons im mikrobiellen Nahrungsgefüge der Darß-Zingster Boddenkette. $\mathrm{PhD}$ thesis, Universität Rostock

Schumann R, Rentsch D (1998) Staining particulate organic matter with DTAF - a fluorescence dye for carbohydrate and protein: a new approach and application of a 2D image analysis system. Mar Ecol Prog Ser 163:77-88

Schumann R, Schiewer U (1994) Influence of abiotic induced phytoplankton changes on protozoan communities from the Darss-Zingst bodden chain (Germany). Mar Microb Food Webs 8:265-282

Simon M, Azam F (1989) Protein content and protein synthesis of planktonic marine bacteria. Mar Ecol Prog Ser 51: 201-213

Simon M, Alldredge AL, Azam F (1990) Bacterial carbon dynamics on marine snow. Mar Ecol Prog Ser 65:205-211

Søndergaard M, Hansen B, Markager S (1995) Dynamics of dissolved organic carbon in a eutrophic lake. Limnol Oceanogr 40:46-54

Sreepada RA, Rivonkar CU, Parulekar AH (1996) Particulate carbohydrate and proteins in the Bay of Bengal. Estuar Coast Shelf Sci 43:295-310

Striquer-Soares F, Chevolot L (1996) Particulate and dissolved carbohydrates and proteins in Lobo Reservoir (Sao Paulo State, Brazil): relationships with phytoplankton. J Plankton Res 18:521-537

Sugimura Y, Suzuki Y (1988) A high temperature catalytic oxidation method for the determination of non-volatile dissolved organic carbon in seawater by direct injection of a liquid sample. Mar Chem 24:105-131

Tsai YL, Tran B, Palmer CJ (1995) Analysis of viral RNA persistence in seawater by reverse transcriptase-PCR. Appl Environ Microbiol 61:363-366

Utermöhl H (1958) Zur Vervollkommnung der quantitativen Phytoplankton-Methodik. Mitt Internat Ver Limnol 9:1-38

Velimirov B (1991) Detritus and the concept of non-predatory loss. Arch Hydrobiol 121:1-20

Verardo DJ, Froelich PN, McIntyre A (1990) Determination of organic carbon and nitrogen in marine sediments using the Carlo Erba NA-1500 Analyser. Deep-Sea Res 37: $157-165$

Wasmund N (1989) Characteristics of phytoplankton in brackish waters of different trophic levels. Limnologica 20: $47-51$

Wasmund N, Kell V (1991) Characterization of brackish coastal waters of different trophic levels by means of phytoplankton biomass and primary production. Int Rev ges Hydrobiol 76:361-370

Williams S, Verity PG, Beatty T (1995) A new staining technique for dual identification of plankton and detritus in seawater. J Plankton Res 17:2037-2047

Zimmermann $\mathrm{H}$, Kausch $\mathrm{H}$ (1996) Microaggregates in the Elbe Estuary: structure and colonization during spring. Arch Hydrobiol Spec Issues Adv Limnol 48:85-92

Zweifel UL, Hagstrøm A (1995) Total counts of marine bacteria include a large fraction of non- nucleoid-containing bacteria (ghosts). Appl Environ Microbiol 61:2180-2185 